Japanese plan speeds up rice \section{genome sequencing}

Tokyo

An international project to sequence the rice genome looks likely to adopt a new goal, following an announcement by the Japanese government that it plans to sequence the entire rice genome by 2004 .

The plan is yet to be incorporated into the new strategy of the 11-nation International Rice Genome Sequencing Project (IRGSP), which will meet in Thailand this month to discuss strategies.

The Ministry of Agriculture, Forestry and Fisheries (MAFF), which leads the Japanese project, says the decision to speed it up was motivated by intensifying competition from the private sector.

But even without such competition, researchers involved in IRGSP say that the pace of the project, which currently aims to sequence the rice genome by 2008 , needs to be accelerated.

"The project's 10-year time scale was too long," says Takuji Sasaki, leader of MAFF's rice genome research programme, who says the new target can be achieved without significant strategic changes.

Sasaki says the project will keep to its plan to map expressed sequence tags (ESTs) of chromosomes 1, 5 and 6 for its initial phase, instead of an earlier proposal to map ESTs of the entire rice genome.

Members of IRGSP called for an accelerated effort when it was revealed in April that Celera Genomics, the US venture set up by geneticist Craig Venter, planned to sequence the entire rice genome using a whole-genome 'shotgun' sequencing technique (see Nature 398, 545; 1999).

MAFF also says it will step up support for rice-genome research as part of a government programme that promotes commercialization of biotechnology research (see Nature 397, 554; 1999).

In its budget proposal for the fiscal year 2000 , the ministry asked for $¥ 7.4$ billion (US\$67 million) for rice genomerelated research, a three-fold increase from this year’s budget, including $¥ 3.6$ billion for sequencing the rice genome.

The budget proposal also includes a project to create a library of full-length rice complementary DNA, and functional genomics projects aimed at identifying and analysing the functions of the genes of economically significant plants.

These efforts will entail a collaboration with universities, industry and other national research institutes. This is seen as a major shift for MAFF, which has sought to conduct its rice-related research in its own laboratories. Asako Saegusa

\title{
Physicists unite to combat a crisis of falling numbers
}

Paris

Presidents of Europe's physics societies met in the UK last week to discuss their growing concern over the lack of students and teachers entering the field.

In Germany, the number of first-year physics students, which peaked at 10,000 in 1991, had fallen to just over 5,000 last year. In Britain, the number of physics graduates training to be schoolteachers collapsed from 568 in 1993 to 181 in 1998.

Similar examples can be seen in most European countries. "It is a crisis situation," says John Lewis, treasurer of the European Physical Society (EPS), which organized the meeting, at Malvern College in Worcestershire, of 50 physicists including 20 presidents of national physics societies.

The American Institute of Physics was also represented. The number of US students completing first degrees in physics is the lowest for 40 years, though the number of graduates in all subjects has quadrupled in that time.

Speakers blamed poor teaching at school and inadequate public understanding. "The image of physics is not good," Lewis says. "People associate it with nuclear disasters. They don't see how it can benefit people."

Sir Arnold Wolfendale, president of the EPS, points to a lack of well trained teachers and to the low salaries they receive. "Teachers

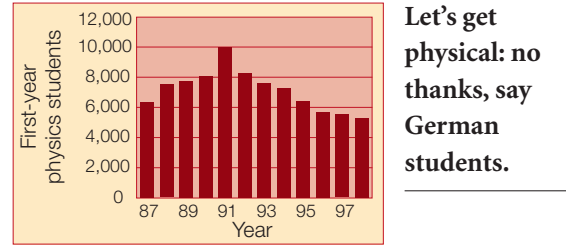

of all sorts have slipped way behind the average pay scale," Wolfendale says. "Unless you get good teachers you don't turn the kids on."

Alexander Bradshaw, president of the German Physical Society, blames low pay for graduate students. "A trend that we have been noticing in several European countries is that physics students are reluctant to get PhDs or go into research," he says. "They are getting good offers from banks or insurance companies. We have benefited too long from the cheap labour of graduate students."

Participants now plan to take their case to national governments and to the European Union. Some have begun projects to promote the image of physics. The EPS is sponsoring a television series about the uses of physics and is producing videos for schools.

Aart Kleyn, president of the Netherlands Physical Society, says the meeting has brought public education to the forefront of issues being considered by physics groups. "These problems are as important as funding, if not more so," he says. Heather Mccabe

\section{India urged to lift map restrictions}

\section{New Delhi}

Under pressure from scientists and industry, the Indian government is to review its restrictions on the dissemination of geographical data collected by its satellites and agencies such as the Survey of India (SOI).

At present, high-resolution maps produced by SOI - the country's only mapmaker - and satellite pictures showing military installations are not available to the public because of national security. And the use of aerial photography is banned unless directly authorized by the defence ministry.

"A lot of scientific and developmental work is suffering in India because of the nonavailability of maps and geodetic survey data," says Madhav Kulkarni, a civil engineer at the Indian Institute of Technology in Mumbai.

Kulkarni was one of 500 participants at the MapIndia-99 conference held last week in New Delhi, which was organized by the Indian Space Research Organization and the Centre for Spatial Database Management and Solutions.
A. R. Das Gupta, deputy director of the Space Application Centre in Ahmedabad, said the centre cannot disseminate its highresolution satellite data because of defence ministry restrictions.

Scientists say that the absence of easy access to 1:50,000-scale maps is placing a major impediment on their work without serving any real security function. One speaker said that there was no public access to $1: 50,000$-scale maps for more than 60 per cent of India's land mass.

Krishnaswami Kasturirangan, chairman of the Indian Space Research Organization, and Valangiman Ramamurthi, secretary of the science ministry, which controls SOI, both say the current policy should be reviewed.

But Ramamurthi says the government has yet to decide on what data restrictions to remove. Given India's security concerns, scientists expect some to stay. The conference called for "a balanced mapping policy that takes care of security concerns without hindering development projects". K. S. Jayaraman 